\title{
Nonlinear Dynamics of Financial Development on Trade Balance
}

\author{
Muhammet Belen ${ }^{1}$ \\ ${ }^{1}$ Faculty of Economics and Business Administration, Karabuk University, Karabuk, Turkey \\ Correspondence: Muhammet Belen, Faculty of Economics and Business Administration, Karabuk University, \\ Karabuk, Turkey. Tel: 90-370-433-3198. E-mail: mbelen@karabuk.edu.tr
}

Received: March 4, 2016

Accepted: April 18, 2016

Online Published: April 25, 2016

doi:10.5539/ijef.v8n5p286

URL: http://dx.doi.org/10.5539/ijef.v8n5p286

\begin{abstract}
The goal of this study is to investigate the non-linear dynamics of financial development on trade balance in Turkey. For the period of 1987Q1-2015Q2, by employing nonlinear autoregressive distributed lag (NARDL) approach to cointegration, it is found that there is cointegration between these variables. This finding suggests that both increase and decrease in financial development have different impacts on trade balance. The relationship between financial development and trade balance has also negative sign. This finding asserts that an improvement in financial development will cause a significant deterioration in trade balance while opposite is also true but with less impact. The results of the study support the empirical literature which has identified the relationship between financial development and growth as being highly correlated. But it does not support using financial development as a policy tool to reduce trade balance.
\end{abstract}

Keywords: financial development, trade balance, real exchange rate, asymmetric cointegration, nonlinear ARDL

\section{Introduction}

Trade balance is the difference between a country's exports and imports. In a country, if exports are greater than imports then trade balance will be in surplus and if imports are greater than exports then trade balance will be in deficit. Trade balance is very important for an economy and it is argued that trade deficit is not good for the long economic growth (Muzammil \& Ahad, 2015).

In this study, the cointegration relationship between financial development and trade balance has been investigated in Turkey, by employing nonlinear autoregressive distributed lag (NARDL) approach to cointegration improved by Shin, Yu, and Greenwood-Nimmo (2014) as an extension of the linear cointegration technique proposed by Pesaran, Shin, and Smith (2001). According to Shin et al. (2014) "the nonlinearity of many macroeconomic variables and processes has long been recognized and nonlinearity is endemic within the social sciences and that asymmetry is fundamental to the human condition" (Keynes, 1936, p. 314; Kahneman \& Tversky, 1979; Shiller, 1993, 2005).

Turkey in the 1960s and 1970s was the developing country following an import substitution strategy. This strategy was successful in manufacturing output but disappointing in exports. Between1970 and 1980, Turkey initiated a first wave of economic reforms to develop a more outward-oriented and market-based economy. In its second wave reforms in the mid-1990s, Turkey continued its trade liberalization efforts. And the reforms of the 2000s were on macroeconomic policy frameworks and structural reforms. Turkey's reform efforts have resulted in a considerably more open and globally integrated economy. The comprehensive and more balanced financial sector reforms have also resulted in a more robust financial system.

Following the establishment of Custom Union with the European Union in 1996, the export market share of manufactured industrial products has increased substantially. For the last six years, manufacturing exports have been about $93 \%$ of total exports (see Table 1). On the other hand, as the Turkish economy has developed beyond the traditional labor-intensive industries, manufacturing has required more raw materials and sophisticated machinery and equipment, most of which continue to be imported (Orhan \& Nergiz, 2014). Because of this import dependent structure of the Turkish economy, any growth in GDP causes to remain high current account deficits. The high and volatile current account deficit in Turkey is detrimental to financial stability and has been at the core of policy discussions in recent years. 
Table 1. Turkey's foreign trade statistics (USD million)

\begin{tabular}{|c|c|c|c|c|c|c|c|c|c|}
\hline \multirow[b]{2}{*}{ Years } & \multicolumn{2}{|c|}{ Exports } & \multicolumn{2}{|c|}{$\begin{array}{l}\text { Manufacturing Exports by } \\
\text { ISIC, Rev. } 3\end{array}$} & \multicolumn{2}{|c|}{ Imports } & \multirow{2}{*}{$\begin{array}{c}\text { Balance of } \\
\text { Foreign Trade } \\
\text { Value } \\
\end{array}$} & \multirow{2}{*}{$\begin{array}{c}\text { Volume of } \\
\text { Foreign Trade } \\
\text { Value } \\
\end{array}$} & \multirow{2}{*}{$\begin{array}{c}\text { Proportion of Exports } \\
\text { Covered by Exports } \\
(\%) \\
\end{array}$} \\
\hline & Value & Change (\%) & Value & $\%$ of Total Exports & Value & Change (\%) & & & \\
\hline 2010 & 113,883 & 11.49 & 105,467 & 0.93 & 185,544 & 31.66 & -71.661 & 299,428 & 61.38 \\
\hline 2011 & 134,907 & 18.46 & 125,963 & 0.93 & 240,842 & 29.80 & -105.935 & 375,749 & 56.01 \\
\hline 2012 & 152,462 & 13.01 & 143,194 & 0.94 & 236,545 & -1.78 & -84.083 & 389,007 & 64.45 \\
\hline 2013 & 151,803 & -0.43 & 141,358 & 0.93 & 251,661 & 6.39 & -99.859 & 403,464 & 60.32 \\
\hline 2014 & 157,610 & 3.83 & 147,059 & 0.93 & 242,177 & -3.77 & -84.567 & 399,787 & 65.08 \\
\hline 2015 & 143,935 & -8.68 & 134,411 & 0.93 & 207,203 & -14.44 & -63.268 & 351,138 & 69.47 \\
\hline
\end{tabular}

Source: TurkStat, Foreign Trade Statistics.

In theory, a country's trade balance depends on its own level of economic activity, the level of economic activity in the rest of the world and the exchange rate, all in real terms. Economic growth at home results in more imports and deteriorates trade balance. On the other hand, economic growth in the rest of the world results in more exports and improves trade balance. By stimulating exports and reducing imports, depreciation at home currency is also expected to improve the trade balance of a country (Bahmani-Oskooee \& Fariditavana, 2015).

In the empirical literature, financial development has also some impacts on trade balance. It is evidenced that countries with a relatively well-developed financial sector have a comparative advantage in industries and sectors that rely on external finance (Kletzer \& Bardhan, 1987). The link between financial development and the structure of the trade balance was explored by Beck (2002). In the study using a 30-year panel for 65 countries, it is evidenced that financial development exerts a large causal impact on the level of both exports and the trade balance of manufactured goods. Countries with a better-developed financial system have a higher export share and trade balance in manufactured goods.

Samba and Yan (2009) investigates the relationship between the level of financial development of a country and its comparative advantage in international trade, by using VAR models. To provide long run relationships between financial development and international trade in manufactured goods, for most of the countries from East Asia they suggest that international trade in manufactured goods enhances financial development.

The empirical question of whether a country's level of manufacturing trade is affected by its financial sector development was also studied by Kiendrebeogo (2012) and he found that countries with better-developed financial systems tend to specialize in industries that rely on external finance in production. He used pure cross-sectional and panel specifications on a sample of 75 countries over the period 1971-2010 and revealed that financial development exerts a positive effect on manufacturing exports strongly and robustly, even after controlling for the effect of banking crises.

For Pakistan, by using time series data from 1972 to 2014, Muzammil and Ahad (2015) have investigated the impact of financial development on trade balance. In the study, it is found that financial development has positive significant impact on trade balance in the long run but in the short run there is no significant relationship between these variables. The study offers government to enhance financial development by managing lending interest rates to improve trade balance.

The relationship between financial development and trade balance requires further empirical work and the existing literature does not provide any evidence regarding impact of financial development on trade balance in the case of Turkey. If financial development has impacts on trade balance, it would mean that financial sector development is also important for economic development and therefore it shows priorities for policy makers.

The rest of the paper is organized as follows: In section 2, the data and methodology which is used in the study are introduced. In section 3, the results of analysis are given. And section 5 concludes.

\section{Data and Method}

The data used in this study has been mainly obtained from IMF data server. The import and export values have been retrieved form IMF Direction of Trade Statistics (DOTS) in US dollar terms. For having an index of financial development, the ratio of total private credits to Nominal Gross Domestic Product (GDP) has been used, all in national currency. The values of private credits have been calculated from the database of Central Bank of Turkey which contains private sector credits of commercial banks, participation banks and development banks. Exchange rate has been defined as national currency per US dollar and consumer price indexes of Turkey and 
US have been used for calculating real exchange rate. Using quarterly data of Turkey, the study has been conducted for the period of 1987Q1-2015Q2.

Instead of using 'exports minus imports', the ratio of exports to imports (X/M) has been used as a proxy for trade balance in the study. This modification of the variable has some advantages. Without modification the variable may have a negative sign and therefore logarithmic transformation cannot be used. By using this ratio the variable also becomes insensitive to nominal values of exports and imports (Bahmani-Oskooee, 1991).

Despite the well-known fact that macroeconomic variables possess asymmetric and nonlinear features (Keynes, 1936; Kahneman \& Tversky, 1979; Shiller, 1993, 2005), research on the relationship between financial development and trade balance has been tested only within a linear framework so far. While there have been some studies about nonlinear relationship between real exchange rate and trade balance (Karamelikli, 2016), nonlinear relationship between financial development and trade balance has not been studied yet. Previous studies have also not included financial development as a key variable in their models.

Following (Muzammil \& Ahad, 2015), the model of this study has been set as below:

$$
L T B_{t}=\alpha_{0}+\alpha_{1} L R E R_{t}+\alpha_{2} L F D_{t}+\epsilon_{t}
$$

In the model, $L T B_{t}$ is defined as $\ln \left(\frac{X}{M}\right)_{t}$, and $R E R_{t}$ is defined as $\frac{E_{t} P^{*} t}{P_{t}}$ where $\mathrm{E}$ is the nominal effective exchange rate, and $\mathrm{P}$ and $\mathrm{P}^{*}$ are the domestic and foreign price levels respectively. LFD represents the ratio of private credits to country's gross domestic product in logarithmic form. While CPI and LRER are used together in the model of (Muzammil, 2015) as independent variable, the CPI variable is omitted in this study to avoid multicollinearity problem.

In this study, an asymmetric cointegration approach is used to estimate asymmetric effect of financial development on trade balance. The nonlinear autoregressive distributed lag (NARDL) model estimates shortand long-run nonlinearities via positive and negative partial sum decompositions of explanatory variables. The asymmetric long-run relationship can be formulated as below:

$$
y_{t}=\beta^{+} x_{t}^{+}+\beta^{-} x_{t}^{-}+u_{t}
$$

where $x_{t}$ is a $\mathrm{k} \times 1$ vector of regressors decomposed as $x_{t}=x_{0}+x_{t}^{+}+x_{t}^{-}$, and $x^{+}$and $x^{-}$are partial sum processes of positive and negative changes in $x_{t}$.

The error correction model (ECM) can be constructed as follows:

$$
\Delta \mathrm{LTB}_{t}=\beta_{0}+\sum_{j=1}^{p} \beta_{1 j} \Delta \mathrm{LTB}_{t-j}+\sum_{j=0}^{q} \beta_{2 j} \Delta \mathrm{LRER}_{t-j}+\sum_{j=0}^{m} \beta_{3 j} \Delta \mathrm{LFD}_{t-j}+\theta \epsilon_{t-1}+e_{t}
$$

where $\Delta$ represents the first differences of the variables and the error-correction term $\varepsilon$ is the OLS residuals series from the long-run cointegrating regression (Equation 1). Putting Equation (1) and Equation (3) together yields following ECM equation:

$$
\begin{gathered}
\Delta \mathrm{LTB}_{t}=\psi+\eta_{0} \mathrm{LTB}_{t-1}+\eta_{1} \mathrm{LRER}_{t-1}+\eta_{2} \mathrm{LFD}_{t-1}+\sum_{j=1}^{p} \beta_{1 j} \Delta \mathrm{LTB}_{t-j}+\sum_{j=0}^{q} \beta_{2 j} \Delta \mathrm{LRER}_{t-j}+ \\
\sum_{j=0}^{m} \beta_{3 j} \Delta \mathrm{LFD}_{t-j}+e_{t}
\end{gathered}
$$

where $\psi=\beta_{0}-\theta \alpha_{0}, \eta_{0}=\theta, \eta_{1}=-\theta \alpha_{1}, \eta_{2}=-\theta \alpha_{2}$. In addition, $\theta=\eta_{0}, \alpha_{1}=-\frac{\eta_{1}}{\theta}, \alpha_{2}=-\frac{\eta_{2}}{\theta}$ are the long run coefficients of LTB, LRER and LFD variables, while $\beta_{1}, \beta_{2}, \beta_{3}$ are the short run coefficients of the variables. In order to determine the existence of asymmetric cointegration relationship between financial development and trade balance, the approach of Schorderet $(2002,2003)$ and Shin et al. (2014) is followed in this study. This approach requires LRER and LFD variables to be decomposed to positive and negative shocks. Then LRER ${ }^{+}$, $\mathrm{LRER}^{-}, \mathrm{LFD}^{+}$and $\mathrm{LFD}^{-}$are the partial sums of positive and negative changes in the LRER and LFD variables. More precisely:

$$
\begin{gathered}
\operatorname{LRER}_{t}^{+}=\sum_{i=1}^{t} \Delta \mathrm{LRER}_{i}^{+}=\sum_{i=1}^{t} \max \left(\Delta \mathrm{LRER}_{i}, 0\right) ; \mathrm{LRER}_{t}^{-}=\sum_{i=1}^{t} \Delta \mathrm{LRER}_{i}^{-}=\sum_{i=1}^{t} \min \left(\Delta \mathrm{LRER}_{i}, 0\right) \\
\mathrm{LFD}_{t}^{+}=\sum_{i=1}^{t} \Delta \mathrm{LFD}_{i}^{+}=\sum_{i=1}^{t} \max \left(\Delta \mathrm{LFD}_{i}, 0\right) ; \mathrm{LFD}_{t}^{-}=\sum_{i=1}^{t} \Delta \mathrm{LFD}_{i}^{-}=\sum_{i=1}^{t} \min \left(\Delta \mathrm{LFD}_{i}, 0\right)
\end{gathered}
$$


Considering Equation (5), the long run relationship in Equation (1) can be redefined as follows:

$$
L T B_{t}=\alpha_{0}+\alpha_{1}^{+} L R E R_{t}^{+}+\alpha_{1}^{-} L R E R_{t}^{-}+\alpha_{2}^{+} L F D_{t}^{+}+\alpha_{2}^{-} L F D_{t}^{-}+\epsilon_{t}
$$

Following Shin et al. (2014) it is straightforward to rewrite Equation (4) in asymmetric form as follows:

$$
\begin{array}{r}
\Delta \mathrm{LTB}_{t}=\psi+\eta_{0} \mathrm{LTB}_{t-1}+\eta_{1}^{+} \mathrm{LRER}_{t-1}^{+}+\eta_{1}^{-} \mathrm{LRER}_{t-1}^{-}+\eta_{2}^{+} \mathrm{LFD}_{t-1}^{+}+\eta_{2}^{-} \mathrm{LFD}_{t-1}^{-}+\sum_{j=1}^{p} \beta_{1 j} \Delta \mathrm{LTB}_{t-j}+ \\
\sum_{j=0}^{q}\left(\beta_{2 j}^{+} \Delta \mathrm{LRER}_{t-j}^{+}+\beta_{2 j}^{-} \Delta \mathrm{LRER}_{t-j}^{-}\right)+\sum_{j=0}^{m}\left(\beta_{3 j}^{+} \Delta \mathrm{LFD}_{t-j}^{+}+\beta_{3 j}^{-} \Delta \mathrm{LFD}_{t-j}^{-}\right)+e_{t}
\end{array}
$$

where $\psi=\beta_{0}-\theta \alpha_{0}, \eta_{0}=\theta, \eta_{1}^{+}=-\theta \alpha_{1}^{+}, \eta_{1}^{-}=-\theta \alpha_{1}^{-}, \eta_{2}^{+}=-\theta \alpha_{2}^{+}, \eta_{2}^{-}=-\theta \alpha_{2}^{-} . \quad$ And $\quad \alpha_{1}^{-}=-\frac{\eta_{1}^{-}}{\theta}, \alpha_{1}^{+}=-\frac{\eta_{1}^{+}}{\theta}, \alpha_{2}^{-}=$ $-\frac{\eta_{2}^{-}}{\theta}, \alpha_{2}^{+}=-\frac{\eta_{2}^{+}}{\theta}$ are asymmetric negative and positive long-run coefficients of the real exchange rate and financial development respectively.

In order to determine the long-run asymmetric cointegration, Shin et al. (2014) proposes the Pesaran et al. (2001) bounds test as in linear ARDL approach. In Pesaran et al. (2001) bounds test, null hypothesis is defined as $\eta_{0}=\eta_{1}=\eta_{2}=0$ against alternative hypothesis $\eta_{0} \neq 0$ or $\eta_{1} \neq 0$ or $\eta_{2} \neq 0$. And for the long-run asymmetry, null hypothesis is $\eta_{0}=\eta_{1}{ }^{+}=\eta_{1}{ }^{-}=\eta_{2}{ }^{+}=\eta_{2}{ }^{-}=0$. Then the calculated F-statistic is compared with the tabulated F values by Pesaran et al. (2001). Null hypothesis of $\alpha_{1}^{+}=\alpha_{1}^{-}$and $\alpha_{2}^{+}=\alpha_{2}^{-}$is tested by the Wald F-test for checking of possible long-run symmetry. To test the existence of short-run symmetry, Wald F-test is used to test the null hypothesis of $\sum_{i=0}^{q} \beta_{2 i}^{+}=\sum_{i=0}^{q} \beta_{2 i}^{-}$and $\sum_{i=0}^{q} \beta_{3 i}^{+}=\sum_{i=0}^{q} \beta_{3 i}^{-}$. When the null hypothesis of symmetry is rejected, the alternative hypothesis that claims asymmetric relationship could be accepted. Then asymmetric dynamic multipliers of $L R E E R^{+}, L R E E R^{-}, L F D^{+}$and $L F D^{-}$could be calculated respectively. The cumulative dynamic multiplier effects of $L R E E R^{+}, L R E E R^{-}, L F D^{+}$and $L F D^{-}$on LTB can be figured out as follow:

$$
\begin{aligned}
& m_{h}^{+}=\sum_{i=0}^{h} \frac{\partial \mathrm{LTB}_{t+i}}{\partial \mathrm{LRER}_{t}^{+}} ; m_{h}^{-}=\sum_{i=0}^{h} \frac{\partial \mathrm{LTB}_{t+i}}{\partial \mathrm{LRER}_{t}^{-}} \\
& w_{h}^{+}=\sum_{i=0}^{h} \frac{\partial \mathrm{LTB}_{t+i}}{\partial \mathrm{LFD}_{t}^{+}} ; w_{h}^{-}=\sum_{i=0}^{h} \frac{\partial \mathrm{LTB}_{t+i}}{\partial \mathrm{LFD}_{t}^{-}}
\end{aligned}
$$

Note that, as $h \rightarrow \infty$ then $m_{h}^{+} \rightarrow \alpha_{1}^{+}, m_{h}^{-} \rightarrow \alpha_{1}^{-}, w_{h}^{+} \rightarrow \alpha_{2}^{+}, w_{h}^{-} \rightarrow \alpha_{2}^{-}$, where $\alpha_{1}^{+}, \alpha_{1}^{-}, \alpha_{2}^{+}$and $\alpha_{2}^{-}$are the asymmetric long-run coefficients. The changes from initial equilibrium to the new point that caused by negative or positive shocks of LRER and LFD is captured by the dynamic multipliers (Shin et al., 2014).

\section{Results}

Equation (7) can be called as Model I. In this model, all variables have asymmetric characteristics and it means that any increase or decrease in independent variables has distinct effects both in short and long-run. As a result, this model is defined as a full asymmetric model.

The contents of Table 2 give evidences of the rejection of null hypothesis of no cointegration in the both models. This table also claims that long-run symmetry is rejected. The null hypothesis of symmetry in the short-run for LFD cannot be rejected in Model I. Tests for basic assumptions of normality, heteroscedasticity and serial correlation are satisfying. By remodeling symmetric pattern of LFD in short-run equation no (9) could be derived.

$$
\begin{gathered}
\Delta \mathrm{LTB}_{t}=\psi+\eta_{0} \mathrm{LTB}_{t-1}+\eta_{1}^{+} \mathrm{LRER}_{t-1}^{+}+\eta_{1}^{-} \mathrm{LRER}_{t-1}^{-}+\eta_{2}^{+} \mathrm{LFD}_{t-1}^{+}+\eta_{2}^{-} \mathrm{LFD}_{t-1}^{-}+\sum_{j=1}^{p} \beta_{1 j} \Delta \mathrm{LTB}_{t-j}+ \\
\sum_{j=0}^{q}\left(\beta_{2 j}^{+} \Delta \mathrm{LRER}_{t-j}^{+}+\beta_{2 j}^{-} \Delta \mathrm{LRER}_{t-j}^{-}\right)+\sum_{j=0}^{m} \beta_{3 j} \Delta L F D_{t-j}+e_{t}
\end{gathered}
$$

Equation (9) is called as Model II and the estimation results for this Model are also presented in the Table 2. The null hypothesis of symmetric relationship in the long-run is rejected for this model and it can be accepted as the best fitted model. The estimation results of full asymmetric model (Model I) and partial asymmetric model (Model II) can be seen in Table 2. 
Table 2. Empirical results of nonlinear relationship

\begin{tabular}{|c|c|c|}
\hline & Full Asymmetry (Model I) & Partial Asymmetry (Model II) \\
\hline INTERSECT & $-0.359158^{* * *}$ & $-0.309315^{* * *}$ \\
\hline LTB $(-1)$ & $-0.734674 * * *$ & $-0.708487 * * *$ \\
\hline LRER_N(-1) & -0.045453 & -0.034324 \\
\hline LRER_P(-1) & 0.113487 & $0.160735^{*}$ \\
\hline LFD_N(-1) & -0.048490 & $-0.069385^{* *}$ \\
\hline LFD_P(-1) & $-0.087940 * *$ & $-0.118572 * * *$ \\
\hline $\mathrm{D}(\operatorname{LTB}(-1))$ & $0.334559^{* * *}$ & $0.318828 * * *$ \\
\hline $\mathrm{D}(\mathrm{LTB}(-2))$ & $0.241724 * *$ & $0.205403 * *$ \\
\hline $\mathrm{D}(\mathrm{LTB}(-3))$ & $0.210952 * *$ & $0.173817^{*}$ \\
\hline $\mathrm{D}(\mathrm{LTB}(-4))$ & $0.248338 * * *$ & $0.203256^{* *}$ \\
\hline D(LRER_N) & -0.173291 & 0.003856 \\
\hline D(LRER_P) & $0.512316^{* * *}$ & 0.532303 \\
\hline D(LRER_N(-1)) & -0.185131 & -0.044821 \\
\hline D(LRER_P(-1)) & $0.628021 * * *$ & $0.567152 * * *$ \\
\hline $\mathrm{D}\left(\mathrm{LFD} \_\mathrm{N}\right)$ & -0.056754 & \\
\hline D(LFD_P) & 0.056801 & \\
\hline D(LFD_N(-1)) & $-0.365291 * *$ & \\
\hline D(LFD_P(-1)) & 0.237155 & \\
\hline $\mathrm{D}($ LFD_N(-2)) & -0.075011 & \\
\hline D(LFD_P(-2)) & $-0.359500 * *$ & \\
\hline D(LFD_N(-3)) & 0.186684 & \\
\hline D(LFD_P(-3)) & -0.227661 & \\
\hline D(LFD_N(-4)) & -0.265706 & \\
\hline D(LFD_P(-4)) & -0.122691 & \\
\hline $\mathrm{D}(\mathrm{LFD})$ & & -0.102354 \\
\hline $\mathrm{D}(\operatorname{LFD}(-1))$ & & $-0.092472 *$ \\
\hline $\mathrm{D}(\operatorname{LFD}(-2))$ & & $-0.253566^{* * *}$ \\
\hline F-statistic & $8.389304 * * *$ & $10.68033^{* * *}$ \\
\hline $\mathrm{R} 2$ & 0.696701 & 0.650037 \\
\hline Jarque-Bera & 0.656730 & 2.488009 \\
\hline Heteroskedasticity F & 0.920784 & 1.183838 \\
\hline Bounds Values & $2.86 \& 4.01$ & $2.86 \& 4.01$ \\
\hline F Bound & 8.060252 & 9.009835 \\
\hline WLR For LFD & $9.695459 * * *$ & 25.51158 \\
\hline WSR For LFD & 0.157980 & - \\
\hline WLR For LRER & $11.00487 * * *$ & 20.59825 \\
\hline WSR For LRER & $13.05562 * * *$ & 8.662775 \\
\hline $\operatorname{ECM}(-1)$ & $-0.418128 * * *$ & \\
\hline
\end{tabular}

Note. $* * * * *$ and $*$ denote statistical significance at the 1,5 and 10 percent levels respectively.

The long-run coefficients of negative and positive decompositions of LRER and LFD are calculated as - 0,048 , 0,227, $-0,098$ and $-0,167$ respectively. As seen in Table 2, LRER is statistically insignificant while LRER $^{+}$, LFD $^{-}$ and $\mathrm{LFD}^{+}$are significant at $\% 10, \% 5$ and $\% 1$ respectively. Therefore we can conclude that positive decomposition of financial development is the most significant among other variables where negative decomposition of real exchange rate is not significant at any level.

The results show that the negative changes in real exchange rate are statistically rejected while positive changes in real exchange rate could be accepted only at $\% 10$ level of significance. The long-run multiplier of negative shocks is not statistically acceptable. While long-run multiplier of positive shocks on real exchange rate is statistically weak, it is estimated as having positive sign. Exchange rate pass-through to domestic prices in Turkey can explain these results. In the theory, there is a positive relationship between real exchange rate and inflation in the long-run (Karamelikli \& Korkmaz, 2016). Therefore, changes in real exchange rate could be reflected on domestic prices. In the economic theory, it is expected that any changes in exchange rate cause price advantages or disadvantages for tradable goods. So in the case of exchange rate pass-through to prices, it can be 
expected that the price advantages or disadvantages are to be eliminated in the long-run.

Long-run multipliers of positive and negative decompositions of financial development are significant at $\% 1$ and $\% 5$ level and the coefficients of both variables are negative. Then an increase in financial development will cause a decrease in trade balance while a negative change in financial development causes a decrease in trade balance less than positive change. Despite of the same signs of both positive and negative decompositions of financial development in the long-run, positive changes have more impact on trade balance.

\section{Conclusions}

In this study, by employing asymmetric autoregressive distributed lag (NARDL) approach to cointegration, the relationship between financial development and trade balance has been investigated. The results reveal that there is cointegration between financial development and trade balance in Turkey. The existence of asymmetric relationship between these variables suggests that any increase or decrease in financial development affects trade balance with different degrees. Therefore, future studies related to this subject should consider asymmetric feature of financial development.

The study also finds that there is a negative relationship between financial development and trade balance. This result supports the literature which suggests that financial development fosters economic growth. In developing countries, financial sector plays a critical role in facilitating economic growth. Financial sector affects domestic savings, capital accumulation, technological innovation and growth. Through economic growth and providing access to financial services, financial development can also impact poverty reduction. Therefore these countries attach great importance to financial development. The findings of this study are convenient with import dependency characteristics of Turkish economy where any growth in GDP causes high current account deficits. Trade liberalization policies may also lead to faster growth of imports than exports in Turkey.

For policy recommendations, this study does offer not to use financial development as a policy tool to decrease trade deficit. Because positive improvements in financial development have negative impacts on trade balance. And positive shocks on financial development have two-fold higher impact than negative shocks. Then policy makers should be aware of the asymmetrical characteristics of financial development as a policy tool considering trade balance.

\section{References}

Bahmani-Oskooee, M. (1991). Is there a long-run relation between the trade balance and the real effective $\begin{array}{llllll}\text { exchange rate of LDCs? } & \text { Economics }\end{array}$ http://dx.doi.org/10.1016/0165-1765(91)90206-Z

Bahmani-Oskooee, M., \& Fariditavana, H. (2015). Nonlinear ARDL approach, asymmetric effects and the J-curve. Journal of Economic Studies, 42(3), 519-530. http://dx.doi.org/10.1108/JES-03-2015-0042

Beck, T. (2002). Financial development and international trade. Journal of International Economics, 57(1), 107-131. http://dx.doi.org/10.1016/S0022-1996(01)00131-3

Kahneman, D., \& Tversky, A. (1979). Prospect Theory: An Analysis of Decision under Risk Daniel Kahneman; Amos Tversky. Econometrica, 47(2), 263-292. http://dx.doi.org/10.1111/j.1536-7150.2011.00774.x

Karamelikli, H. (2016). Linear and Nonlinear Dynamics of the Turkish Trade Balance. International Journal of Economics and Finance, 8(2), 70-80. http://dx.doi.org/10.5539/ijef.v8n2p70

Karamelikli, H., \& Korkmaz, S. (2016). The Dynamics of Exchange Rate Pass-Through to Domestic Prices in Turkey, 39-48. http://dx.doi.org/10.17261/Pressacademia.2016

Keynes, J. (1936). The general theory of employment, interest and money. London: Macmillan. Retrieved from http://cas.umkc.edu/economics/people/facultyPages/kregel/courses/econ645/Winter2011/GeneralTheory.pdf

Kiendrebeogo, Y. (2012). The Effects of Financial Development on Trade Performance and the Role of Institutions. Economics Bulletin, 32(3), 2546-2559.

Kletzer, K., \& Bardhan, P. (1987). Credit markets and patterns of international trade. Journal of Development Economics, 27(1-2), 57-70. http://dx.doi.org/10.1016/0304-3878(87)90006-X

Muzammil, M., \& Ahad, M. (2015). Impact of Financial Development on Trade Balance: An ARDL Cointegration and Causality Approach for Pakistan. Retrieved from https://mpra.ub.uni-muenchen.de/id/eprint/68829

Orhan, O. Z., \& Nergiz, E. (2014). Turkey's Current Account Deficit Problem and Its Effects on the European Union Accession. İstanbul Gelişim Üniversitesi Sosyal Bilimler Dergisi, 1(1), 137-158. Retrieved from 
http://dergipark.ulakbim.gov.tr/igusbd/article/view/5000037702

Pesaran, M. H., Shin, Y., \& Smith, R. J. (2001). Bounds testing approaches to the analysis of level relationships. Journal of Applied Econometrics, 16(3), 289-326. http://dx.doi.org/10.1002/jae.616

Samba, M. C., \& Yan, Y. (2009). Financial Development and International Trade in Manufactures: An Evaluation of the Relation in Some Selected Asian Countries. International Journal of Business and Management, 4(12), 52-69. http://dx.doi.org/10.5539/ijbm.v4n12p52

Schorderet, Y. (2002). A Nonlinear Generalization of Cointegration: A Note on Hidden Cointegration (No. 2002.03). Genève. Retrieved from http://www.unige.ch/ses/dsec/repec/files/2002_03.pdf

Schorderet, Y. (2003). Asymmetric cointegration (No. 2003.01). Cahiers du département d'économétrie, Faculté des sciences économiques et sociales, Université de Genève. Retrieved from http://www.unige.ch/ses/metri/cahiers/2003_01.pdf

Shiller, R. J. (1993). Macro Markets: Creating Institutions for Managing Society's Largest Economic Risks. Clarendon Press.

Shiller, R. J. (2005). Irrational Exuberance (2nd ed.). Princeton University Press.

Shin, Y., Yu, B., \& Greenwood-nimmo, M. (2014). Modelling asymmetric cointegration and dynamic multipliers in a nonlinear ARDL framework. In R. C. Sickles, \& W. C. Horrace (Eds.), Festschrift in Honor of Peter Schmidt Econometric Methods and Applications (pp. 281-314). http://dx.doi.org/10.1007/978-1-4899-8008-3

\section{Copyrights}

Copyright for this article is retained by the author(s), with first publication rights granted to the journal.

This is an open-access article distributed under the terms and conditions of the Creative Commons Attribution license (http://creativecommons.org/licenses/by/3.0/). 